\title{
Consumer Social Responsibility: Example of Cycling Service
}

The article presents research on consumer social responsibility based on the example of cycling service. The author analyses the tourism sector determining a relation between socially responsible behaviour of an organization and consumer behaviour.

Keywords: social responsibility, cycling tourism, consumer behaviour, tracking research, social responsibility of organization.

Straipsnyje pristatomi vartotojų socialinès atsakomybès tyrimo rezultatai analizuojant dviračių paslaugas kaip pavyzdị. Analizuojant su turizmo sektoriumi siejamą atveji, straipsnyje nustatoma socialiai atsakingos elgsenos sąsaja tarp organizacijos ir jos vartotojo.

Raktiniai žodžiai: socialinè atsakomybè, dviračių turizmas, vartotojų elgsena, stebėsenos metodas, organizacijos socialinè atsakomybè.

\section{Introduction}

The fast changing economic and social environment, increasing competition in the market and decreasing natural environmental resources, as well as changing values of society forces suppliers and consumers to be concerned not only about profit but also to take social responsibility of their business. According to J. Vijeikis (2011), consumer social responsibility is considered as an engine of wealth and economic sustainable development. Consumer social responsibility consists of product and service creation and its environmental, social, financial and ethical aspects (Vijeikis, 2011).
In Lithuania, only very small part of organisations and customers are socially responsible (Juščius, Dragienè, 2015). However, social responsibility as a tendency of socially responsible business and socially responsible consuming is getting more popular in the democratic world (Juščius, Dragienė, 2015). Customers are more and more interested in social responsibility of business organisations (Ozkan, 2009). They would like to see these organisations as socially responsible though the paradox is that not always they, as consumers, choose product or service responsibly (Carroll, Shabana, 2010; del Mar Alonso-Almeida, de Navarrete, 
Pomeda, 2015). Thus, using cycling service as an example, the problem of this article is based on the analysis how the consumer is socially responsible.

The context of cycling service was taken as an example of the active tourism service. According to M. Kučinskienè and A. Mačerinskienė (2014), development of cycling tourism could bring great results in developing regions, small business organisations and create possibilities to get incomes in small towns. Furthermore, tourism was determined as one of the most important economic sector that last year had the growth of about $4.5 \%$ (WTO, 2017). This means that the amount of consuming is growing fast and consumers make impact on the social responsibility of consuming. Even more, the tourism sector is characterized by a great diversity, integrity and multiplicity. Thus this sector is changing very fast adapting innovations, environmental and social changes (Armaitienè, Vaškaitis, 2013).

According to the raised problem, the object of this article is consumer social responsibility.

The aim of this article is to determine consumer social responsibility using cycling service as an example.

To reach the aim, there were set several tasks:

1. To theoretically determine an impact of organization's social responsibility on consumer behaviour;

2. To empirically determine consumer social responsibility based on the example of cycling service.

The author employed the following research methods: literature review, observation of consumers.

\section{Impact of organization's social responsibility on consumer behaviour}

Only some Lithuanian organisations are socially responsible (Juscius, Dargiene, 2015). Though this situation is changing fast, because the idea to be socially responsible grows fast in the minds of organisations and consumers. Consumers influence social responsibility of business organisations by responsibly choosing their products (Brimerienè et al., 2013). Thus consumer behaviour is important determining possibilities to improve social responsibility of the business.

Consumer social responsibility could be identified through the care about responsible consuming taking into account ecological, social and ethical issues.

Consumers' purchase process consists of five steps (Kotler, Armstrong, 2014): identification of needs, search of information, evaluation of alternatives, decision making, and behaviour after the purchase. This process is important to analyse and understand as there is the need to manage consumer behaviour. Consumers' behaviour concerning social responsibility might be a decision to purchase or a refuse to purchase a certain product. The social responsibility of the consumer as some criterion appears during the evaluation of alternatives and it is applied to consumer's decision to purchase product and his/her reaction after the purchase (Brimeriene, 2010). Consumers show the trust to the business organizations that care for environmental resources and take responsibility for its sustainable development. Thus, consumer social responsibility might influence production process, marketing process and even healthy development of society. It could help to solve 
environmental issues and influence the growth of economy.

\section{Consumer social responsibility}

Social responsibility, as the consumers' purchase criterion, frequently is not the primary one in choosing the product. Scientists maintain (Shabana, Carroll, 2010; del Mar Alonso-Almeida, de Navarrete, Pomeda, 2015) that this issue is influenced by lack of information, passiveness of customers and an incorrect choice of research methods. Lack of information is determined as the main reason restricting social responsibility of consuming (Uusitalo, Oksanen, 2004; Durif et al., 2010; Jusčius, Maliauskaite, 2015). People would be much more responsible consumers if they have enough information about the organization and its products. If the consumer knows that purchasing the product would help to solve some issues, they are more motivated to be responsible consumers (Jusčius, Maliauskaitè, 2015). But researches prove (Irwin, Walker, 2009) that consumers are more motivated by selfish motives than by social. Even more consumers agree that organizations should be socially responsible, but they are not sure if they agree to pay more for product.

In present days the consumer behaviour could be described as a consumption culture in which consumption culture has been spreading all over the world with also the influence of globalization, it should not be limited to only defending one's right or purchasing goods of high quality and those which are reliable, but making a new definition of the "conscious consumer" covering also all the aforementioned social, environmental and ethical activities and adoption of this definition by also the consumers is required (Bugday, Babaogul, 2016).

Social responsibility is defined as consuming when the consumer makes purchasing his/her decision not just to satisfy his/her needs but takes care about consequences to environment and society of his/her decision (Ozkan, 2009). It could be stated that a socially responsible consumer combines three aspects:

- Influence of organization to consumers behaviour;

- Consumer's recycling habits;

- Reduced use of the products harmful to the environment.

According to national development of organizations' social responsibility, the socially responsible consumer cares about ethical, social and ecological issues (for more see: https://www.e-tar.lt/portal/lt/ legalAct/TAR.F49A22DBB0C0).

T. M. Devinney et al. (2006) maintain that consumer ethics is one of the main social aspects while making impact on social responsibility of business. N. C. Smith (2007) relates consumer social responsibility to rational and honest ethics when consumer is interested in social responsibility of an organization while thinking about choosing and purchasing a product. It seems that socially responsible and ethical consuming are almost the same concepts but in this article unethical consuming is understood as illegal copping of documents, music or similar behaviour. Ethical behaviour and consuming is related more with honest purchase and use of products. Socially responsible consuming is assumed as useful to society and environment.

There are two types of the socially responsible consumer (Gonzalez, Korchia, 2009): 
- Responsible to environment (the consumer does not by products from the companies that bring harm to the environment);

- Responsible to society and wealth of consumers (the consumer does not by products from the companies making negative impact on society and the wealth of consumers).

Research by C. Roux and J. Nantel (2012) showed that consumers identify themselves more as friendly customers rather than as being socially responsible. According to consumers' perception (Roux, Nantel, 2012), the consumer is socially responsible when he/she is nicely behaving in the environment. But C. Roux and J. Nantel (2012) declares that to be a socially responsible consumer means to care about the environment as well as about the wealth of society and safety of the family. Socially responsible consumers should choose products according to their social level. A consumer becomes socially irresponsible when he/she is purchasing product regardless of his/her social level.

According to different perspectives of socially responsible consuming there could be stated that consuming is responsible when he/she cares about social issues, environmental issues, and ethical norms in the society (Figure 1).
According to F. Durif et al. (2010) and J. Bray et al. (2011), consuming is irresponsible if purchasing is determined assuming only the price, quality and convenience, also if it is difficult to find information about organization's social responsibility. A customer rarely searches for information about social responsibility of an organization intentionally. But even if they try to search, it is difficult because organisations place information about their activities concerning their social responsibility and other in complicated forms (Kozar, Connell, 2013). It seems that marking of products with special labels would be easier for customers to notice about social responsibility of producer. Though there are so many labels of products in the market that consumers get confused (Durif et al., 2010).

There are proved that consumers are more motivated to be responsible if the purchasing product helps to solve some issues. It seems that the information sources used by consumers have impact on consumer's decision (Kozar, Connell, 2013). The media has traditionally focused on intrigue rather than problem solving. There is need of reliable information in the market to form responsible consuming. Even more there are found (Bray et al., 2011; Kozar, Connell, 2013) that consumers are often sceptical about

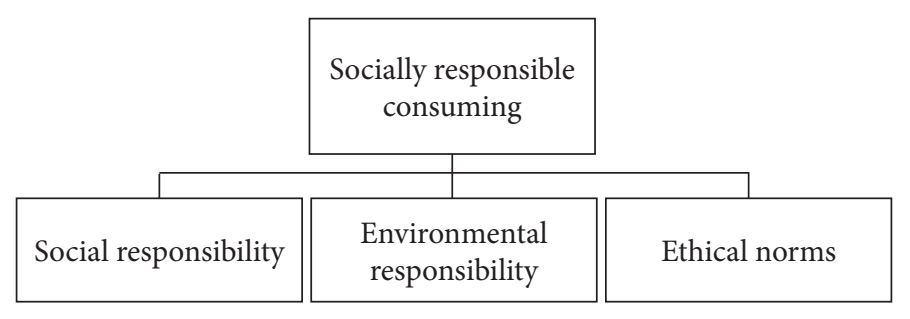

Fig. 1. Socially responsible consuming

Source: created by the author according to C. Roux, J. Nantel (2012). 
corporate social responsibility declarations and regard them as unfair marketing, which uses consumer credibility and thus only increases product prices. Accordingly, there should be mentioned that duplicate information does not give consumers the necessary motivation to take social responsibility.

Another issue why consumers prevent from taking socially responsible decisions is the difference between attitude and behaviour of consumer. During research (Vermeir, Verbeke, 2006) there were found that people declare their social responsibility but behave is irresponsible.

Some other scientists (Valort, 2008; Irwin, Walker, 2009) found that consumers understand differently the same social issues. Some consumers are taking care of how to protect the environment while others care about human rights. In the purchase moment consumers try to assess if their behavior makes a difference solving problem. This assessment makes influence on consumer behavior (Unsitalo, Oksanen, 2004; Vermeir, Verbeke, 2006).

\section{Research methodology}

According to some scientists (Irwin, Wallker, 2009; Bray et al., 2011), it is possible to identify the factors responsible for consumer social responsibility: peers, family, religion, price and quality of product or service, opportunity to express their attitude and values, availability of ethical products or services, attractiveness of the manufacturer, etc. On the other hand, there could be defined criterions that could be measured during research with the purpose to assess social responsibility of consumer (Table 1).

The criterions for measuring social responsibility of consumer were chosen according to the scientific literature review and the purpose to determine social responsibility of consumer using cycling service example. The cycling service is a part of active tourism and as it was said on the introduction tourism was determined as one of the most important economic sector that last year growth was about 4.5\% (WTO, 2017). This means that the

\section{Criteria used to measure consumer social responsibility}

\begin{tabular}{|l|l|}
\hline \multicolumn{1}{|c|}{$\begin{array}{c}\text { Criteria used to measure consumer } \\
\text { social responsibility }\end{array}$} & \multicolumn{1}{c|}{$\begin{array}{c}\text { Scientific source used to identify } \\
\text { the chosen criterion }\end{array}$} \\
\hline Polluting the environment & Čiegis, Arbušauksaite, 2007 \\
\hline Disturbing peace of others & Babachinaite, 2008; Pitrėnaitė, 2011 \\
\hline Traffic disturbance & Cupcake, 2013 \\
\hline Destruction of nature & Čiegis, Arbušauksaite, 2007 \\
\hline Irregular parking for bikes & Cupcake, 2013 \\
\hline Hazards for pedestrians & Cupcake, 2013 \\
\hline Breaking of rented bike & Cupcake, 2013 \\
\hline Small vandalism & Čiegis, 2009 \\
\hline Drunk and cycle & Babachinaite, 2008; Pitrènaite, 2011 \\
\hline Invalid carriage of people & Cupcake, 2013 \\
\hline
\end{tabular}

Source: created by the author. 
amount of consuming is growing fast and these consumers make impact to social responsibility of consuming. Even more tourism sector is characterized by a great diversity, integrity and multiplicity. Thus, this sector is changing quite fast adapting innovations, environmental and social changes (Armaitienè, Vaškaitis, 2013). These are the main reasons to survey consumer's social responsibility using cycling service example.

As a survey method was chosen observation of consumers. The observation as a method was chosen because it is one of the best ways to gathered social data about behaviour (Kardelis, 2007) but not just attitude. People tend to think better about themselves and while filling the questionnaire mark their attitude (Kardelis, 2007; Shoval, Ahas, 2016). Thus tracking the customers let us gather behavioural data objectively.

Here in this research was chosen tracking of consumers who rented a bike and were cycling it in the park of Birštonas resort in Lithuania. The rented bikes were marked thus there was avoided mistakes of tracking non-rented bike.

The tracking place was near the bike renting place but in the very open space and public space to be sure of tracking the right bike and to be able to assess all criterions of consumer's social responsibility. The tracking conditions were outside natural conditions. The tracking time was with the curtain periodicity.

An observer was always the same person (The author of this article is very grateful to Edgaras Kriščiūnas, who made a huge work gathering the research data). He could be seen but he could not be recognized by consumer as researcher. According to ethical principles you do not need permission to observe objects in the public space. Thus the gathering method was legally right and ethical.

Sample size was made according to saturation principle (Vitkutè-Adžgauskienè, 2011). Thus gathering the data was combined with analyses of observed data. After 13 separate observing periods the researcher noticed that gathering data repeats and the new observing time is not necessary. Every separate observing took three hours and at the same time of day. The research was made in 2016. During all research time 385 persons were observed: $45 \%$ of females and $55 \%$ of males.

\section{Research results}

The observed research data shows that women $(25 \%)$ are more socially responsible customers in cycling service than men (75\%), because $7.1 \%$ of all males (Figure 2) and just $2.9 \%$ of females were observed as leaving the garbage somewhere but not in the trash bin.

Analysing the social responsibility criterion of consuming 'Disturbing peace of others' (Figure 2), there were no much differences between women and men. Though men were six percent points more $(53 \%$ of all irresponsibly behaving persons) disturbing peace of others than women ( $47 \%$ of all irresponsibly behaving persons). Irresponsible behaviour was assumed if a cycling person was rude while riding a bike, was too loud, was disturbing pedestrians or people actively and calmly spending leisure time.

The same situation was observed evaluating the criterion 'Traffic disturbance' (Figure 2) and also the criterion 'Disturbing peace of others'. While observing cycling people the irresponsible activity was kept when they interfered with the passage. 


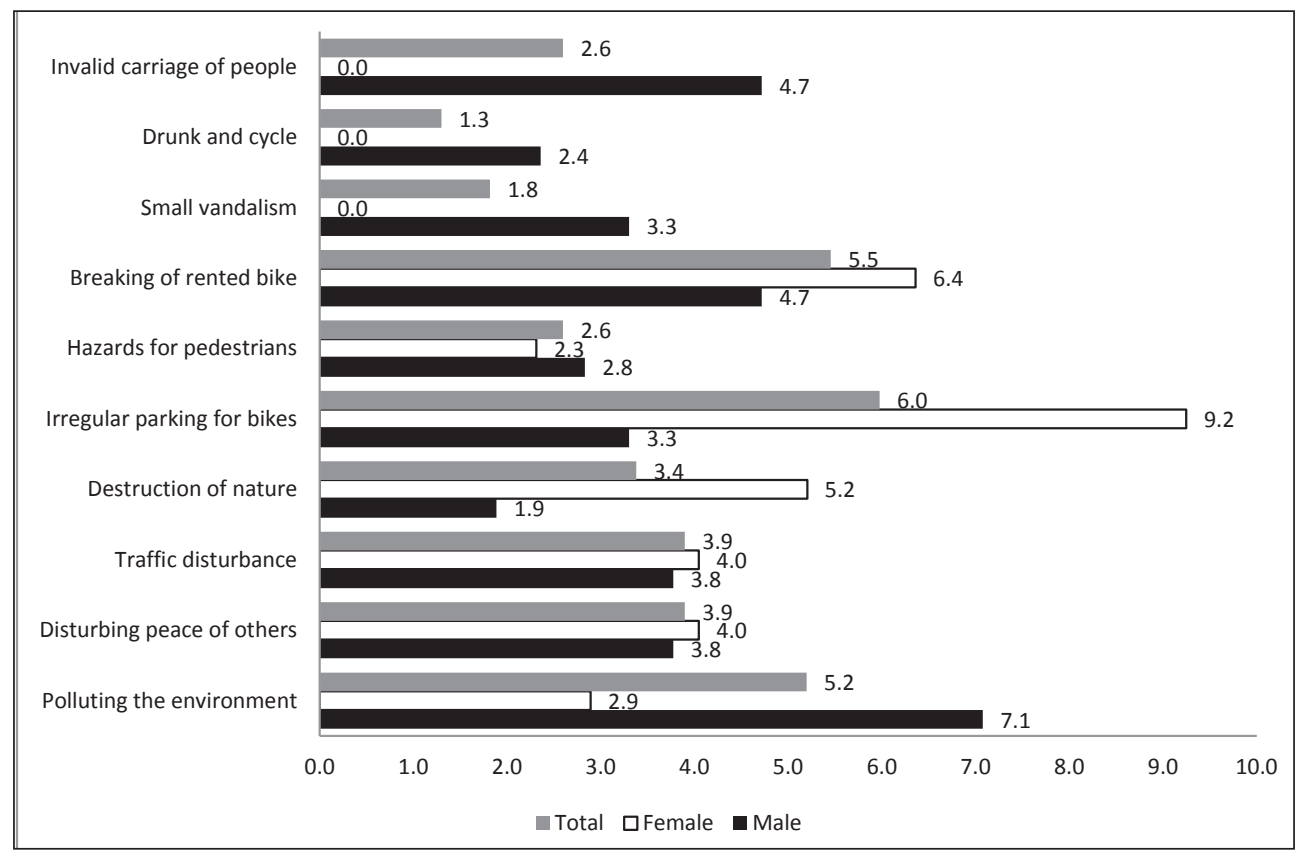

Fig. 2. Assessed criteria of consumer social responsibility in cycling

Note: percentage counted of 100 percent of the observed people sample.

$5.2 \%$ of females $(69 \%$ of all irresponsibly behaving persons) and $1.9 \%$ of males (31\% of all irresponsibly behaving persons) were active destructing the nature. Women more often were riding or leaving the bike on the grass.

Observing irregular parking of bikes there was found that $9.2 \%$ of females $(70 \%$ of all irresponsibly behaving persons) and only $3.3 \%$ of males (30\% of all irresponsibly behaving persons) were irresponsible socially at this point (Figure 2). The irresponsible behaviour was fixed if the cycling person left bike not in the regular parking place, and this kind of parking made troubles to other people. There should be mentioned that in total $6 \%$ of the respondents were behaving irresponsibly, and it is the biggest percentage from all research. This means that seeking to develop social responsibility there should be thought how to assure an order and a neat while parking the bike.

The observation showed that only $2.3 \%$ of females and $2.8 \%$ of males were making hazard for pedestrians (Figure 2). The irresponsible behaviour was fixed when the cycling person was driving directly to pedestrians not trying to ride around pedestrian or even inform them with the bell. The total $2.6 \%$ of this kind of irresponsible behaviour is not high. But it is very rude behaviour and very dangerous behaviour of cycling people. Thus, development of social responsibility should work on explaining to society what and how some irresponsible behaviour might be harmful to others. 
The second highest 5.5\% rate of the total respondents was 'Breaking the rented bike', i.e., $6.4 \%$ of women and $4.7 \%$ of men were behaving irresponsible with the rented bikes (Figure 2). It means that still a lot of people think that if it is not my item, I do not have to take care of it and even I could break it. This behaviour has impact on the profit of bike renting companies, because it much more increases their expenses on bike repair.

'Small vandalism' was observed as a criterion that shows responsibility of a person in the park and the resort town Birštonas. The irresponsible person was observed if he/she was breaking the sports facilities in the park or trying to break or to paint on the sculptures in the park. Tracking research showed that only male respondents were socially irresponsible at this point (3.3\%, Figure 2).

The research data showed that none of the female respondents and $2.4 \%$ of males used the bike rent service being drunk (Figure 2). However, the law does not allow to ride a bike being drunk. It means, that some people behave not just socially irresponsible but even dangerously breaking the law. At the same time, here should be mentioned that renting company was behaving irresponsible and breaking the law too because its employees must not rent a bike to a drunk person.

'The invalid carriage of people' showed that none of the females and $4.7 \%$ of males behaved irresponsible while carrying other people or even children on the bike (Figure 2 ). This behaviour might make influence on the health of others, thus it is assumed as socially irresponsible behaviour.

\section{Discussion}

The research on tracking showed irresponsible behaviour of consumers in Birštonas resort park. According to R. Čiegis and A. Arbušauksaite (2007), social responsibility is related to respect of the environment and nature. Therefore, the consumer breaking the rules and harming the nature is harmful to the society and it might make influence on the future generations (Čiegis, 2009).

The research results showed that there are some consumers who disturb the traffic and peace of others and breaks the law and the rules in the traffic. According to Cupcake (2013) this means that socially irresponsible behaviour poses a risk to pedestrians and might course some issues to an organisation. Accordingly, the reputation of an organisation might be influenced, and a socially responsible consumer might decide not to use the service of an organisation, which does not care about safety, i.e., socially responsible behaviour of its consumer.

Social irresponsibility of the consumer while breaking the law (driving being drunk and unproperly carrying other people on the bike) shows low social responsibility related to town, environment and society. Thus B. Pitrénaite (2011) and G. Babachinaitè (2008) propose to develop security fields like the crime, the civil and the fire safety, the traffic safety, the public health and accidents. At the same time there should be created and developed the socially responsible community. The role of this community would be citizens showing respect and complying with the law regulations. 


\section{Conclusions and solutions}

1. Literature review showed that the consumer should be educated as a conscious and socially responsible person. This is important for saving the environment for both the consumer and the business. As business cannot survive without the consumer, therefore the consumer should care about social responsibility of business. It means he/ she has to be a conscious consumer in the purchasing process.

2. The data analysis shows that cycling people mostly behave socially responsibly. But according to several assessed criteria of social responsibility there could be distinguished some issues of social responsibility of cycling people.

Based on the analysis of the observed data there could be stated that irrespon- sible behaviour was mostly tracked in irregular parking of bikes, breaking the rented bike and destruction of the nature. However, there was still tracked the most dangerous socially irresponsible behaviour as hazard for pedestrians, riding a bike being drunk, and improper carriage of other people. Dangerous and irresponsible behaviour of consumers shows irresponsibleness of the bike renting business. Thus, socially responsible behaviour of the consumer would also change the business behaviour. Socially responsible behaviour of an organisation should be motivated by consciousness and socially responsible purchasing behaviour of the consumer. At the same time, the organisation should show initiative to develop a socially responsible consumer. Such kind of behaviour could become a competitive advantage of the organisation in the socially responsible consuming market.

\section{References}

1. Armaitienè, A., Vaškaitis, E. (2013). Turizmo inovacijų taikymo Lietuvos turizmo versle prielaidos // Tiltai. Vol. 4, pp. 19-35. Internet access: <http://journals.ku.lt/index.php/tiltai/ article/viewFile/473/pdf $>$ [accessed September 11, 2017].

2. Babachinaite, G. (2008). Smurtinio nusikalstamumo samprata, tendencijos ir šiuolaikiniai raiškos ypatumai Lietuvoje // Jurisprudencija. Mokslo darbai. Vol. 1, No. 103, pp. 16-21. Internet access: <http://etalpykla.lituanistikadb.lt/fedora/get/LT-LDB0001:J.04 2008 1367160905979/DS.002.0.01. ARTIC $>$ [accessed September 11, 2017].

3. Bray, J., Johns, N., Kilburn, D. (2011). An Exploratory Study into the Factors Impeding ethical consumption. // Journal of Business Ethics. Vol. 4, pp. 597-608. doi: 10.1007/s10551-0100640-9.
4. Brimerienè, I., Čeponytė, Z., Dagiliūtè, R., Drulytè, I., Gapšyte, V., Maldeikienè, A., Ščeponavičienè, S., Venckevič, E. (2013). Atsakingas vartojimas, Mokytojo knyga. - Lietuvos vartotojų institutas. Internet access: <file://C:/ Users/Laima/Downloads/atsakingas_vartojimas_knyga.pdf $>$ [accessed September 11, 2017].

5. Bugday, E. B., Babaogul, M. (2016). Conscious Consumer Scale: The Study of Validity and Reliability // Asian Journal of Social Sciences \& Humanities. Vol. 5(2), pp. 119-134. Internet access: <https://www.researchgate.net/publication/313726278> [accessed September 11, 2017].

6. Čiegis, R. (2009). Gamtos išteklių ir aplinkos ekonomika. - Klaipėda: KU leidykla.

7. Čiegis, R., Arbušauskaitè, A. (2007). Gyvenimo sąlygų Klaipèdos mieste kiekybinis tyrimas. Iš: 
Urbanizacijos procesas ir aplinka: Mokslo studija. - Klaipèda.

8. Cupcake, L. (2013). Don't Bike Like a Dickweed: 10 Rules for New Cyclists. Internet Access: $<$ http://tinyfixbikegang.com/dont-bike-likea-dickweed-10-rules-for-new-cyclists/ > [accessed September 11, 2017].

9. del Mar Alonso-Almeida, M., de Navarrete, F.C.F., Pomeda, J. R. (2015). Corporate Social Responsibility Perception in Business Students as future Managers: A Multifactorial Analysis // Business Ethics: A European Review. Vol. 24(1), pp. 1-17. doi: 10.1111/beer.12060.

10. Devinney, T. M., Auger, P., Eckhardt, G., Birtchnell, T. (2006). The Other CSR: Consumer Social Responsibility // Leeds University Business School Research Papers Series. Research Paper No. 15-04, pp. 1-12. Internet access: <https:// papers.ssrn.com/sol3/papers.cfm?abstract_ $\mathrm{id}=901863>$ [accessed September 11, 2017].

11. Durif, F., Boivin, C., Rajaobelina, L., Lecompte, A. (2010). Socially Responsible Consumers: Profile and Implications for Marketing Strategy // International Review Research Papers. Vol. 6, pp. 215-224. Internet access: http:// bizresearchpapers.com/14.\%20Fabien.pdf > [accessed September 11, 2017].

12. Gonzalez, C., Korchia, M. (2009). How do Socially Responsible Consumers Consider Consumption? An Approach with the Free Associations Method // Research et Applications en Marketing. Vol. 3, pp. 25-41. doi: http://doi. org/10.1177/205157070902400301.

13. Irwin, J. R., Walker Naylor, R. (2009). Ethical Decisions and Response Mode Compatibility: Weighting of Ethical Attributes in Consideration Sets Formed by Excluding Versus Including Product Alternatives // Journal of Marketing Research. Vol. XLVI, pp. 234-246. doi: http:// doi.org/10.1509/jmkr.46.2.234.

14. Juščius, V., Dragienė D. (2015). Socialiai atsakingas vartojimas Lietuvoje: vartotoju charakteristikos // Tiltai. Vol. 2, pp. 47-65. doi: http:// dx.doi.org/10.15181/tbb.v71i2.1100.

15. Jusčius, V., Maliausskaitè, D. (2015). Socialiai atsakingą vartojimą lemiantys veiksniai ir ji ribojančios priežastys. // Regional Formation and Development Studies. Vol. 1 (15), pp. 65-72. doi: http://dx.doi.org/10.15181/rfds.v15i1.980.

16. Kardelis, K. (2007). Mokslinių tyrimų metodologija ir metodai. - Šiauliai: Liucijus leidykla.
17. Kotler, Ph. T., Armstrong, G. (2014). Principles of Marketing, $15^{\text {th }}$ Ed. - UK: Pearson Prentice Hall, UK.

18. Kozar, J. M., Connell, K. Y. H. (2013). Socially and Environmentally Responsible Apparel Consumption: Knowledge, Attitudes and Behaviors // Social Responsibility Journal. Vol. 2, pp. 315-324. doi: https://doi.org/10.1108/SRJ09-2011-0076.

19. Kučinskienė, M., Mačerinskienè, A. (2014). Can Cycling Lead to Regional Development? // Regional Formation and Development Studies. Vol. 2, pp. 18-29. doi: http://dx.doi. org/10.15181/rfds.v13i2.826.

20. Ozkan, Y. (2009). The Effect of Some Demographic Characteristic of Turkish Consumers on their Socially Responsible Consumption Behaviors. // World Applied Sciences Journal. Vol. 7, pp. 946-960. Internet access: < https:// www.idosi.org/wasj/wasj6(7)/12.pdf > [accessed September 11, 2017].

21. Pitrènaité, B. (2011). Management Theory and Studies for Rural Business and Infrastructure. Saugios savivaldybès kūrimo Lietuvoje gairès. Kaunas: Mykolo Romerio universitetas.

22. Roux, C., Nantel, J. (2012). Conscious Consumption and its Components: An Exploratory Study // Advances in Consumer Research. Vol. 36, pp. 903-904. Internet access: <http:// www.acrwebsite.org/volumes/v36/NAACR_ v36_108.pdf > [accessed September 11, 2017].

23. Carroll, A. B., Shabana, K. M. (2010). The Business Case for Corporate Social Responsibility: A Review of Concepts, Research and Practice // International Journal of Management Reviews. pp. 5-105. doi: 10.1111/j.14682370.2009.00275.x.

24. Shoval, N., Ahas R. (2016). The Use of Tracking Technologies in Tourism Research: The First Decade // An International Journal of Tourism Space, Place and Environment. Vol. 18(5), pp. 587-606. doi: http://www.tandfonline.com/ doi/full/10.1080/14616688.2016.1214977.

25. Smith, N. C. (2007). Consumers as Drivers of Corporate Responsibility. The Oxford Handbook of Corporate Social Responsibility. pp. 281-302. - NY: Oxford University Press Inc.

26. Uusitalo, Q., Retta Oksanen, R. (2004). Ethical Consumerism - a View from Finland // International Journal of Consumer Studies. Vol. 28(3), pp. 214-221. doi: 10.1111/j.14706431.2003.00339.x. 
27. Valor, C. (2008). Can Consumers Buy Responsibly. Analysis and Solutions for Market Failures // Journal of Consumer Policy. Vol. 3, pp. 315-326. doi: https://doi.org/10.1007/ s10603-008-9070-9.

28. Vermeir, I., Verbeke, W. (2006). Sustainable Food Consumption: Exploring the Consumer Attitude - Behavioural Intention Gap // Journal of Agricultural and Environmental Ethics. Vol. 19(2), pp. 169-194. doi: 10.1007/s10806-005-5485-3.

29. Vijeikis, J. (2011). Inovacijų vadyba. - Vilnius: Jotema.

30. Vitkutè-Adžgauskienė D. (2011). Kokybinių HSM tyrimų duomenų igijimo, autorinių teisių užtikrinimo, archyvavimo, dokumentavimo ir sklaidos sistemos sukūrimo galimybių studija. Internet access: < http://www.lidata.eu/files/ images/Kokybiniu.pdf $>$ [accessed September 11, 2017].

31. WTO (2017). 2016 Annual Report. World Tourism Organization. Internet access: http://www.eunwto.org/doi/pdf/10.18111/9789284418725 > [accessed September 11, 2017].

The paper submitted: September 11, 2017 Prepared for publication: December 10, 2017

\section{Laima JESEVIČIŪTĖ-UFARTIENĖ}

\section{SOCIALIAI ATSAKINGAS VARTOTOJAS: DVIRAČIŲ PASLAUGŲ PAVYZDYS}

\section{$\mathrm{S}$ a $\mathrm{n} \mathbf{t} \mathbf{r}$ a u $\mathrm{k}$ a}

Straipsnyje siekiama pristatyti vartotojų socialinès atsakomybès tyrimo, atlikto su dviračių nuomos paslaugas besinaudojančiais vartotojais, rezultatus. Dèl šios priežasties straipsnyje analizuojama, kaip mokslininkai supranta organizacijų socialinę atsakomybę ir kokią ịtaką ši daro vartotojų elgsenai. Atitinkamai straipsnyje jivertinta, jog mokslineje literatūroje nustatytas ryšys tarp organizacijos atsakingos elgsenos ir vartotojo elgsenos. Todel yra žinoma, kad vartotojų socialinė atsakomybė keičia požiūrị i organizaciją ir jos veiklas rūpintis socialinès atsakomybès valdymu organizacijoje. Be to, vartotojo socialinè atsakomybe gali būti suprantama kaip ekonominès gerovès ir vystymosi variklis. Vis dèlto vartotojas ne visada socialiai atsakingai renkasi produktus ar paslaugas. Todèl straipsnio objektu pasirinkta vartotojų socialinė atsakomybè.

Vartotojų socialinè atsakomybė yra produktų ir paslaugų kūrimo, jų aplinkos, socialinių, finansinių ir etinių aspektų sudedamoji dalis. Straipsnyje pasirenkama analizuoti turizmo sektoriuje veikiančias dviračių nuomos paslaugas, kurios kaip turizmo sektoriaus dalyvis keičiasi pagankamai greitai dèl adaptuojamų inovacijų, aplinkos ir socialinių pokyčių. Tad straipsnio tikslas yra nustatyti vartotojų socialinę atsakomybę, remiantis dviračių nuomos paslaugų tyrimu.

Straipsnio tikslui pasiekti suformuluoti du uždaviniai:

1. Teoriškai nustatyti organizacijos socialinès atsakomybès reikšmę vartotojų elgsenai.
2. Empiriškai nustatyti dviračių nuomos paslaugomis besinaudojančių vartotojų socialinę atsakomybę.

Straipsnio uždaviniams ịgyvendinti taikomi du metodai: mokslinès literatūros analizè ir stebėsenos.

Mokslinès literatūros analizė parodè, kad vartotojus reikia mokyti būti socialiai sąmoningais ir atsakingais. Tokios vartotojų elgsenos skatinimas padètų tausoti ir saugoti aplinką, tiek nuo socialiai neatsakingo vartotojo, tiek nuo socialiai neatsakingos verslo organizacijos. Tokia sąsaja tampa reikšminga organizacijų socialinei atsakomybei tada, kai vartotojai renkasi produktus ar paslaugas sąmoningai iš socialiai atsakingų organizacijų. Orientuojan-

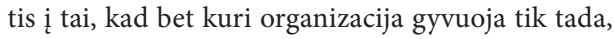
kai turi vartotojų, galima teigti, kad vartotojas turi rūpintis, jog verslas būtų socialiai atsakingas.

Tyrimą pasirinkta atlikti stebint vartotojus, besinaudojančius išsinuomotais dviračiais. Stebèsena kaip tyrimo metodas pasirinktas dèl to, kad žmonès yra linkę apie save galvoti geriau nei iš tiesų elgiasi. Dèl šios priežasties stebèsenos metodas tampa objektyvesnis už anketinę apklausą ar interviu. Tyrimas atliktas Birštono kurortiniame parke. Naudojant saturacijos metodą, iš viso suplanuota ir ịvykdyta 13 stebėsenos laikotarpių, o jų metu užfiksuotos 385 respondentų elgsenos.

Stebėsenos metu surinkti tyrimo duomenys parodè, kad dviračių nuomos paslaugomis besinaudojantys vartotojai yra pakankamai socialiai atsakingi. Vis dèlto užfiksuota ir socialiai 
neatsakinga elgsena - netinkamas dviračių statymas, išsinuomotų dviračių laužymas, gamtos ir aplinkos niokojimas.

Stebėsenos tyrimas atskleidè, kad pasitaiko ir ypač pavojingos socialiai neatsakingų vartotojų elgsenos - pésčiųjų taranavimas, alkoholio vartojimas važiuojant dviračiu, nesaugus keleivių vežimas dviračiu. Dviračių paslaugų vartotojų socialiai neatsakinga elgsena parodè, kad dviračių nuomos paslaugas teikianti organizacija demonstruoja socialiai neatsakingą elgseną, nes nesirūpino vartotojų socialiai neatsakinga elgsena. Dèl šios priežasties organizacijų socialiai atsakinga elgsena turètų būti skatinama tiek vartotojų sąmoninga socialine paslaugų pirkimo elgsena, tiek pačios organizacijos rodoma iniciatyva vystyti socialiai atsakingą vartotoją. Tokia organizacijos elgsena galètų tapti konkurenciniu pranašumu socialiai atsakingoje vartojimo rinkoje. 